Vol. 3: (June) 2013

\title{
Muslim Politics in Malaysia and the Democratization Process
}

\author{
LUKMAN THAIB ${ }^{1}$
}

\begin{abstract}
This article will address the Muslim politics in Malaysia in the light of the broader shifts towards democratization and Islamization by focusing on politics among the majority ethnic Malay community, followed an overview of the ideological rivalry between UMNO and PAS, with special reference to the electoral performances of these parties in the past three general elections (November 1999, March 2004 and March 2008). It then explores the underlying reason for the perceived importance of Islam in understanding the voting trend among the Malay-Muslim electorate which raised the question to what extent was the discourse on Islam instrumental in persuading the Malays to switch their support from PAS to the UMNO during the 2004 elections, and in the process of continued participation as an 'Islamic Party' in Malaysian mainstream politics what factors were that encouraged the PAS leaders to compromises and to play by the 'rule of democracy'. In the concluding part of the article the writer also provide with an overview on reform agenda of Civilizational Islam (Islam Hadhari) under premiership of Tun Abdullah Ahmad Badawi and the current Malaysia's Transformation Programme (GTP) under the leadership of Dato' Sri Mohd Najib Tun Abdul Razak.
\end{abstract}

Keywords: democratization process, Muslim politics in Malaysia, Islam Hadhari, Government Transformation Programme (GTP)

With the declining influence of leftist ideas and the so-called 'crisis of authoritarianism' in Muslim Middle East, North Africa and Southeast Asia, democracy seems poised to offer itself as a viable alternative. By the early 1990s, terms such as pluralism (al-ta'addudiyah), civil society (mujtama' madani), human rights (huquq al-Insan), freedom (hurriyah) and transparency (shafafiyyah) have become buzzwords in the discourse among scholars and activists alike (Haddad 1995: 76). Islamic activism too had shown signs of moving away from the radical 'fundamentalist' phase of 1970 s and 1980s to a 'participatory phase' characterized by a preference to work within the system and by a neo-reformism that questioned the traditional role of faith, its leadership, organization, priorities and interpretation (Wright 1992: 33).

A parallel development was seen in the experiments with political liberalization made by the ruling elites, which led to the emergence of 'Salvation Party' in Algeria, al-Nahdhah party in Tunisia and the Freedom and Justice Party (FJP) and Salafiyyah al-Nour party in Egypt and the AKP party in Turkey. These democratic experiments can be regarded as the shift in the orientation of Islamic activism. The general scenario then has been a series of shifts by both the dissident Islamists and the regimes they were challenging: the former in direction of championing democracy and participation, the latter in the direction of Islamization. This section of this article explores contemporary Muslim politics in Malaysia in the light of these developments. It focuses on the relationship between the two major competitors in MalayMuslim politics, the United Malays National Organization (UMNO), and the dominant component in the National Front (NF) coalition government, and the opposition Islamic Party (PAS), both operating in the socio-political reality of multi-ethnic Malaysia as well as in the

\footnotetext{
${ }^{1}$ Lukman Thaib, Ph.D., Consultan at the Dept. of Islamic Political Science (Siyasah Shar'iyyah), University of Malaya, 50603 KUALA LUMPUR, Malaysia. Email: cottring@yahoo.com.
} 
'unique Islamic experience, of its history (Esposito 1996: 124-149). It analyses these shifting trends and their implications for the future of Muslim politics and democracy in Malaysia.

\section{Malay-Muslim Politics: PAS from Radical Islam to Islamic Democracy}

The Pan- Malaysian Islamic Party (PAS), a breakaway UMNO faction, was formed in 1951 and is the main opposition party with the capacity to undermine the National Front's (NF) influence among rural Malays (Farish 2004: 17-45). Although PAS emphasized on Islamic roots and Islamic terminologies, but Islam as a system of governance was not placed at the forefront of the party's agenda in the first three decades of its existence (Ahmad Hussein 2002: 75-107). In fact, the party congress in 1954 rejected a motion seeking the immediate establishment of an Islamic state. The party's objective of Islamic governance was to be achieved incrementally through educating the public and nurturing an Islamic society, and through democratic means. However, PAS still neither portrayed UMNO and the government as Islamic and democratic, nor did it represent the interest of the Malay masses. It accused UMNO leaders and these non-Muslim coalition partners of promoting un-Islamic policies and encouraging decadent Western cultural influences.

Among the opposition parties, PAS today has the most strongly defined objective. As a party motivated by Islam, PAS is principally devoted to the formation of an Islamic state in Malaysia. Accordingly, it espouses policies and ideas that are rooted in Islam. Adopting this preponderant Islamic posture, PAS has been offering Malaysians, Muslim Bumiputeras in particular, a vision of a society reformed through legislation based on religious tenets (Edmund 2007: 1-23). The establishment of an Islamic state, according to the party, will bring about spiritual regeneration and lead to the development of a more just, democratic, moral, principled and socially conscious society, devoid of repressive legislation and unhealthy economic activities such as gambling.

Although in the Malay heartland, especially in Kelantan and Terengganu, PAS has consistently enjoyed staunch support, estimated at 35-40 per cent of the electorate (Edmund 2007: 8), and enabled it to mobilize sufficient support to secure control of Kelantan state legislature in 1990 and retain control of it in the general election in 1995, 1999 and 2004. However, PAS leaders aware that their party could not win the national power by its own. The party's electoral performances have been exceptional only when it has cooperated with other parties, as evident during the general elections of 1974, 1990 and 1999 (Edmund 2007: 8).

When PAS was a member of the UMNO-led ruling National Front (NF) coalition from December 1972 until November 1977, the Islamic party secured 14 parliamentary seats and 46 state seats during the 1974 election. In 1990, when PAS was a member of the opposition coalition, the APU (Angkatan Perpaduan Ummah or Muslim Unity Movement), comprising an UMNO breakaway faction, the party regained control of Kelantan after a 13-year hiatus, won seven parliamentary seats and 33 state seats. PAS remained a member of APU from April 1989 until 1996, when this coalition dissolved (Edmund 2007: 9).

In 1999, PAS became a member of another opposition coalition, the Alternative Front (Barisan Alternatif), comprising prominent opposition parties such as the Democratic Action Party (DAP) and Parti Keadilan Rakyat (Peoples Justice Party=PKR) (Hong 1997,10), an organization linked to former UMNO deputy president, Anwar Ibrahim. During the general elections held that year, PAS registered a remarkable electoral performance, securing control of another state government, in Terengganu, and winning an unprecedented 27 parliamentary seats and 98 state seats, doubling its previous best performance in 1974 of 14 parliamentary and 46 state seats when it was a member of National Front (NF).

Whatever the situation was, it is necessary to remember here that although in the formative years between 1951 and 1956, PAS was 'a political party in name only, but until today PAS remains the main opposition to the UMNO, the electoral trends over the past 15 years suggest that the Islamic party did not gain ground over the National Front (NF) because of its Islamic stance. PAS's national influence is limited, and it is unable to record electoral gains 
outside of the Malay world-the party secured a state seat in the state of Johor for the first time in its history by default.

\section{The Islamization of the United Malays National Organization (UMNO)}

British indirect rule in the Malay Peninsula kept intact the privileges of the nine traditional sultans and the aristocratic classes but stripped them of real power. As compensation, the sultans were given control over 'Malay culture and religion'. Official Islam under the patronage of the royal houses, with some powers over religious education, devotional matters and a limited corpus of personal and family laws affecting Muslims, was thus institutionalized (Gullick 1987: 37).

An early Malay response to colonial ruled took the form of the modernist-reformist movement that emerged in the 1920s and 1930s.It was led by Muslim scholar-journalists who advocated ideas reason and modernity against the conservatism and the docility of the traditionalists who dominated the official Islam of the colonial state (Roff 1967: 37). This young faction (Kaum Muda) movement failed to dislodge the old faction (Kaum Tua) in the state Islamic bureaucracy. The movement was rendered ineffective by the actions of the authorities that ranged from physical force to official fatwas that prescribed the Kaum Muda's ideas as 'deviationist'. The Kaum Muda's pan -Islamism failed to attract mass Malay support and its rejection of the Malay royalty, which symbolized Malay political claim on the now multi-ethnic country, exacerbated the feeling of insecurity among the Malays.

For all its failings, the modernist movement marked the beginning of organized Muslim politics among the Malays. It helped place Islam at the centre-stage of Malay politics. It brought substantive socio-political themes into public Islamic discourse beyond the traditional concern with personal piety. Its rise and decline also saw the emergence of elements of synthesis and symbiosis in Malay-Muslim politics. By the 1950s, the traditional place of Islam had become distinctly 'modernist'. Some of the key terms of Islamic modernism-reason, modern education, economic development, constitutional government and Muslim unity-had become part and parcel of the official Islamic lexicon. The mass movement transformed itself in 1946 into the United Malays National Organization (UMNO) with Dato' Jaafar, a member of the Johor Royal Family and a district officer in the colonial administrative service, as its president. Disagreement over non-Malay participation in national politics led to Dato' Onn's resignation in 1951. He was succeeded by Tunku Abdul Rahman Putra, brother of the then Sultan of Kedah.

UMNO described itself as a liberal nationalist party dedicated to Malay political dominance but committed to democracy, the free market, inter-ethnic harmony and 'Western traditions of a secular state (Funston 1980: 23). It forged an alliance with a Chinese businessman-dominated organization called the Malayan Chinese Association (MCA) and the Malayan Indian Congress (MIC), led mainly by Indian professionals to contest elections to the Federal Legislative Council in June 1955. This multi-ethnic Alliance won 51 of the 52 seats contested. It continued to stand for elections on a common platform of moderation, ethnic compromise and economic development, but with each component expected to mobilize support from its own ethnic constituency. The 1957 independent Constitution of Malaya (now referred to as Peninsular Malaysia following the entry of the British colonies of Sabah and Sarawak in 1963 into the larger Federation of Malaysia) called for a federation of the eleven states, a constitutional monarchy and a parliamentary democracy modeled after British.

The Constitution also safeguarded the position of the nine Malay sultans who would take turns to become the country's king for five year periods. It provided for Malay as the national language, affirmative action privileges for Malays in education, employment and business opportunities, and prescribed Islam as the official religion. UMNO had insisted on these provisions as a 'compensation' for the 'Malay loss of exclusive nationhood'. Both UMNO and PAS, in varying degrees, had demanded that it must be the indigenous Malays who would determine the nature and future of the land (Hong Hai 1997: 10). The provision for Islam allowed state funds to be utilized for religious activities and for the shari'ah courts to enforce the limited body 
of personal and family laws applicable to Muslims. The UMNO leadership made it clear that the constitutional article on Islam as the religion of the federation did not in any way imply an Islamic state (Ahmad 1997: 27).

The evolution of UMNO as the leading component of the ruling party can be divided into three eras. The first was between independence in 1957 and the racial riots following the May 1969 elections under the leadership of Tunku Abdul Rahman and 'an alliance between Malay aristocrats, bureaucrats and Chinese business in the context of an economy dominated by foreign capital' (Crouch 1996: 76). It can be described as a period of liberal democracy and continuity of the colonial administration structures. The second, between 1969 and 1981 and under Abdul Razak and Hussein Onn, was the beginning of an era of 'retreat from the secular path' by introducing the Malay economic nationalism. The third period under Mahathir from 1981 onwards can be divided into an earlier period of liberalism and, beginning from the late 1980s, a period of 'modified authoritarianism' (Crouch 1996: 76) which continues with the impressive economic growth and by purposeful identification with Islam.

The first generation leaders of UMNO were attentive to the symbols of Islam. The UMNO Constitution has as one of its objectives the defense and expansion of Islam. UMNO insisted on Islam as the official religion of the federation against the reservations of the Malay sultans fearful of losing their last bastion of power. To address this fear, Islam was constitutionally listed as the prerogative of the states and under the headship of the sultans (Hashim 1963: 117). Even UMNO leaders insisted that its interest in Islam was not based on political expediency; external pressures had clearly been a catalyst.

The question of how to deal with the Islamists was uppermost in Mahathir's political agenda when he took office in 1981. Unlike his predecessors, Mahathir was more prepared to accommodate the dissenting Islamists. Even before assuming office, he had expressed a willingness to increase the role of Islam in society and governance. This helped persuade the ABIM leader Anwar Ibrahim to accept Mahathir's invitation to join UMNO just prior to the 1982 elections.

Among Mahathir's earlier policy statements as prime minister was one on the 'assimilation of Islamic values in the administration'. The policy was described as 'an effort to strike a balance between the spiritual and material' which would proceed with 'incremental, moderate implementation... taking into account the sensitivities of the non-Muslim population' (Ahmad Hussein 2002: 75-107). It was not a radical policy redirection; it was not about creating an Islamic state or implementing the Islamic law (shari'ah). Nevertheless, the policy was the most purposeful expression of an Islamization process that UMNO had ever made.

The programmes were many and varied. Aware of the value of the 'politics of symbolic action', the emphasis on the symbolic-the use of Islamic terminologies and salutations, the building of Islamic complexes, international conferences, research institutes, Islamic programmes on radio and television, Islamic courses for the public-continued with increased vigour. But more substantive programmes were added to the list: the establishment of an international Islamic university; the introduction of Islamic securities, banking and insurance systems; amendments to the Constitution to give increased powers to Islamic legal authorities, reforms of Islamic administration, laws and courts; and serious efforts to promote uniformity and coordination between states. In the realm of law, the most contested terrain in Islamic politics, 'nowhere in Asia has the Islamization of law proceeded more methodically than in Malaysia...dozens of new statutes and judicial decisions have clarified, expanded, and reformulated the law applicable to Muslims ' (Harrowitz 1994: 22).

Following PAS, impressive victory in the 1999 elections, Mahathir and his successor, Abdullah Ahmad Badawi, became preoccupied with ways and means to counter the rising tide against the UMNO, particularly the Malay heartland (Khadijah 2007: 138-153). As PAS' popularity among the Malays began seriously undermine the UMNO's hegemony, the NF (BN) government actively started promoting what it termed was 'a more moderate and tolerant brand of Islam'. The UMNO began actively condemning the ostensibly radical Islam propagated 
by PAS, claiming that it was threatening national unity. The UMNO also asserted that PAS has manipulated Islam to achieve its political objective of securing power.

As a means to counter what Mahathir believed that PAS was form of political Islam, he felt that his successor as prime minister had to possess adequate, if not impressive, Islamic credentials that could help his party win back the support of many disillusioned Malays. Mahathir himself would admit that Abdullah was chosen as his deputy because of the latter's impeccable Islamic credentials which could be used to help win over the hearts and minds of rural voters. Abdullah was also seen as the only leader who could help unite the divided Malay community following the Anwar Ibrahim debacle.

\section{Abdullah Premiership}

After more than 20 years of Mahathirism, on 1 November 2003, Mahathir retired from public office, handing the premiership to his chosen successor, Abdullah Ahmad Badawi. It is believed that one credible reason for his decision to retire was his fear that if he remained in office, UMNO's stranglehold on power would have been seriously jeopardized given his declining support among rural Malays, long the party's traditional bastion of support. During the 2004 general elections, Abdullah led the $\mathrm{NF}(\mathrm{BN})$ to an extra ordinary electoral victory where the ruling coalition secured more than 90 per cent of the seats in parliament, severely undermining the opposition and closing a long chapter in Malaysian political discourse on reformation agenda.

After Abdullah took over the premiership he introduced new initiatives that would help discard the idea that his premiership would be conditioned by the many legacies of his predecessor. More importantly, Abdullah was particularly concerned with the need to rebuild UMNO's image as a party committed to championing the interests of the Malays.

Abdullah's most important contribution to Malaysian politics was his promotion of his own personal imprint of a form of Islam acceptable to all Malaysians. Civilizational Islam (Islam Hadhari) can be interpreted as an attempt by Prime Minister Abdullah to dissociate himself from the type of Islam promoted by Mahathir, a practice of faith that was apparently far too biased towards the idea of material development with inadequate attention to matters spiritual. The Abdullah government introduced the concept of Islam Hadhari in the UMNO/NF (BN) manifesto for the 2004 general elections. In his election campaigns, Abdullah repeatedly stressed that while his Islam Hadhari was progressive and inclusive, PAS' understanding of Islam, that it wanted to foist on all Malaysians, was reactionary and exclusive. For Abdullah, Islam Hadhari was suitable and relevant in the context of Malaysia's multi-ethnic and multireligious society.

The Civilizational Islam (Islam Hadhari), as espoused by Abdullah, served to achieve two basic goals. First, the concept helped to situate the role of Islam and the Muslim community (ummah) in the context of the development of the Malaysian economy. Muslims would be encouraged to seek knowledge, namely in science and technology, which could, in turn, help improve the socio-economic standing of the community (ummah) as well as generate economic growth. Second, Islam Hadhari would help bridge differences between Muslims and nonMuslims, thus serving to overcome racial polarization that remained a serious problem in the country (Khadijah 2007: 139).

Although Abdullah made a concerted effort to articulate his understanding of Islam Hadhari, most analysts appeared baffled about the difference between this concept and that of the Islamic agenda of past UMNO led NF (BN) government. What was clear with the introduction and active propagation of Islam Hadhari was that for both UMNO and PAS, Islam was seen as the most important and effective means to secure political support. UMNO, however, hoped that with Islam Hadhari, the party had found a means to propagate a concept that though inherently divisive in the Malaysian context, yet was one that could attract the support of non-Muslims as well. One analyst would note that Abdullah's Islam Hadhari had made quite an impression on members of the non-Muslim community (Lah Yi 2004). 
Leaders of the Western world also appeared enamoured by Abdullah's Islam Hadhari, seen primarily in the comment they made during the Malaysian prime minister's official visits to the US, France and Britain a few months after the March 2004 elections. For example, British Prime Minister Tony Blair described Malaysia as a model Islamic country that should be emulated by the rest of the Muslim world (New Straits Times 2004).

\section{Mohd Najib Ascension as Prime Minister}

Since the aftermath of the 8th March 2008 general election, the Malaysian political landscape went through a number of upheavals with questions raised over the continuing viability of National Front coalition rule and the future socio-political direction of the country. No one predicted that National Front (NF) would suffer the worst loss since its establishment in 1974 (Chamil 2009: 169-180). NF leaders themselves believed that they would suffer some losses, but not to the extent that NF would lose a two-thirds majority in parliament or that NF would lose control of four states (Kedah, Pulau Pinang, Perak and Selangor). However, the unexpected happened during the March 2008 elections. In the previous general elections which were held on March 21, 2004, Abdullah was handed a majority victory in parliament; four years later the results were completely different.

The final results were approximately double the predicted swing of less than 15 per cent, or 30 to 40 parliamentary seats. The NF coalition won just 140 of the 222 parliamentary seats on offer and only 51.2 per cent of the valid popular vote (O'Shanessy 2008: 88-109). All of the main component parties of the NF suffered. In fact, the NF majority in parliament hinged upon its support in Sabah and Sarawak where it won 55 of the 57 parliamentary seats on offer. In contrast, all of the opposition parties posted remarkable gains with the PKR increasing its presence in parliament from a seat in 2004 to 31 seats in 2008, PAS secured 23 seats compared to its 7 seats in 2004 and the DAP won 28 seats, up from its previous seats. These gains increased the total opposition presence in parliament to 82 seats from 21 seats in 2004 (O' Shanessy 2008: 98).

Realising the fact that there was growing pressure for him to step down, and the anxiety amongst UMNO members was not abating, and at the same time the opposition led by Anwar Ibrahim continued to bring defeat to the (National Front or Barisan Nasional), Abdullah finally decided to step down and Dato' Seri Mohd Najib was appointed as the sixth Prime Minister on 3 April 2009. Although his successes may be attributed to the fact that he is the son of Malaysia's second Prime minister, Tun Abdul Razak, where the groundwork was laid out for him by his late father, however, it is important to be note that although he was afforded the opportunity to succeed in the political arena, it was ultimately his own efforts, intelligence, political savvy, merits, and courage which allowed him to grasp the most significant political prize of all, that of becoming Malaysia's Prime Minister.

\section{Mohd Najib's Transformation Programmes}

As a politician, Mohd Najib is not only a realist but he is also a pragmatist, who is not fanatical about any one particular ideology, as he himself explained, as a pragmatic person he said: "I believe in beginning policies which can fulfill national policies" (Chamil 2009: 189). This means if the national policies may be achieved by embracing a free market economy, then he in favor of that. If, in order to achieve national policy requires the involvement of the government, that would also be considered. As far as approach is concerned, his emphasis is on what one may achieve in the real world.

\section{Malaysia Vision}

After becoming Prime Minister, Mohd Najib pledged to make a huge transformation to the country by introducing his '1 Malaysia, People First, Performance Now' as a way to accelerate Malaysian’s performance in order to make Malaysia into a developed nation by 2020. According 
to him unity amongst Malaysians is a pre-condition to achieving the Vision 2020 aspirations. He believes that for a country to develop, its people must first advance by embracing diversity in ethnicity, religion and beliefs and by being inclusive through building mutual respect and acceptance, such that a solid foundation of trust and cohesiveness exists. Only as a united people, according to him, Malaysia can embark on the broader development of Malaysia's nation. Mohd Najib added that "the Bangsa Malaysia concept was not aimed at imposing Malay culture on other races, but to further strengthen multiracial Malaysia. It is about bonding and working together for the benefit of all Malaysians. Ultimately we share the wealth of the country together" (Yeoh 2009: 43-48).

Mohd Najib's concept of 1 Malaysia stressed on respect for the diversity amongst various ethnic groups of the Malaysian society and leverages this diversity as a competitive asset for the nation. The spirit of his ' 1 Malaysia' was completely different from the 'Malaysian Malaysia' slogan advocated by the Democratic Action Party (DAP) which rejected the very idea of special rights for the Malays. It was also different from the New Malaysia ideology which rejected the notion of Malay supremacy and wanted the special treatment accorded to the Malays and other bumiputras be abolished. Mohd Najib's concept emphasizes on inclusiveness through the acceptance of differences and encourages all Malaysians to embrace the unique qualities of each group (PM Dept. 2009: 54-55). Ultimately the principle of fairness to all is the underpinning of Mohd Najib's '1 Malaysia'. Nevertheless, according to him this fairness must account for their different levels of development.

Mohd Najib recognized that the affirmative elements of the New Economic Policy (NEP) were still needed in terms of its pledge to correct the historical imbalances which had thus far sidelined the rural Malays. But he also gave the impression that changes would be made drawing on healthy competitive elements. This meant that Malay and bumiputera corporations would compete amongst themselves, against one another, and against non-Malay corporations. He insisted that "More bumiputera companies should be prepared to compete because when they compete, the best of what they have to offer will become manifest" (Wariya 2009: 185). Mohd Najib admitted that eradicating the groups that depend on commissions would not be easy and could not be done overnight. However, according to him: "The best way forward, for their interests and for the interests of this nation, is to adopt open competition, be it amongst the bumiputra community or free competition for all" (Chamil 2009: 185).

\section{New Economic Model (NEM)}

The second initiative of Mohd Najib was the New Economic Model (NEM). The main reason for introducing this $N E M$ was the realization that with the increasing challenge in the global environment, he believed that the elements of Malaysia's economy will need to be structurally upgraded in order for the country to avoid the middle income trap and to increase the growth rate. Mohd Najib is aware that the country cannot afford to coast along and he made it clear even before he became Prime Minster that a transformation of the Malaysian economy is a necessity. In his letter to the 'Wall Street Journal' in March 2009, he stated that "Malaysia will invest in education and technology, further strengthening Malaysia's capacity to lead in information technologies, renewable energy and emerging sectors of the new economy... We are remaking Malaysia once again" (Yeoh 2009: 34-36). Malaysia needs a model which is more relevant to current times. Noor Mohamed Yackop, Minister in the Prime Minister's Department stated to the World Bank team of experts: "To move to a higher income-based economy, we have to move towards a knowledge and innovation-based economy where skilled labour is needed... We are trapped in a middle-income gap" (Mohamed 2009: 56).

This New Economic Model (NEM) is currently being developed by the National Economic Advisory Council (NEAC) to guide the economic strategy of Malaysia. This will be reinforced by the Tenth Malaysia Plan (2011-2015). According to Mohd Najib, the difficult move from a middle-income to a high-income economy does not necessarily mean venturing into completely new sectors. It may also mean using a strategy of building on the sectors in which Malaysia has 
already demonstrated levels of competitiveness, such as in services such as tourism, ICT, finance and Islamic banking, especially industries such as green technology, electronics manufacturing and resource-based industries.

Among the most important challenges in achieving the $N E M$ objective is to move up the value chain e.g., from pure assembly to more technology-intensive products and services, from labour-intensive and low value-added activities towards innovation-based activities that add more value. In addressing the skill requirements needed to move towards a high-income economy, the Government is taking a holistic approach, which addresses, among others: 1. Reforming education towards producing skills demanded by industry; 2. Creating supportive policies toward nurturing, attracting and retaining the most talented people of Malaysia;3.Devising appropriate policies for low-skilled and high-skilled foreign labour to meet skill shortages, and; 4. Promoting an efficient labour market (Mohd Najib 2009: 54-60).

In short, Mohd Najib believes that to move towards becoming a high-income nation requires specialized production and specialized exports. According to him, Malaysia cannot afford to cast our net too wide and spread our human capital, financial incentives and R\&D resources too thinly (Mohd Najib 2009: 54-60). "The intense international competition dictates that Malaysia must excel in the areas we choose to pursue", he added.

\section{Economic Transformation Programme (ETP)}

The ETP is the first time that any effort of this kind has been undertaken in Malaysia's history. This is a comprehensive effort that will transform Malaysia into a high-income nation by 2020 . The programme provides strong focus on a few key growth areas (engines): the 12 National Key Economic Areas (NKEAs). These NKEASs are expected to make substantial contributions to Malaysia's economic performance, and they will receive priority from public investment and policy support. The 131 entry point projects (EPPS) have been identified that correctly outline actions required to grow the Malaysian economy. The Malaysian government is aware that with an increasingly challenging global business environment the country needs a fundamentally new economic model in order to become a high-income nation with a per capita income of about RM 48,000 or USD 15,000 in 2020. To achieve high-income status by 2020 the country will require an annual real growth rate of about 6 percent in the next 10 years.

Among the measures which have been designed by the Malaysian government to achieve high-income status is that the country needs to remain sustainable in both economic and environmental terms, meeting present needs without compromising those of future generations. This means that the country will achieve growth without running down its own natural resources. In addition to that Malaysia also will reduce its dependence on petroleum and liquid gas as the primary economic contributor, and to ensure fiscal sustainability the government will encourage private sector-led investment as a means to avoid dependence on public funding. Since the objective to make Malaysia a high income nation is not just a quantitative target only, but also how to make Malaysia an advanced, developed nation with high-income economy characteristics, the way in which the country grows to achieve this objective will be inclusive in nature which will provide opportunities for all Malaysians to share in the benefit by encouraging employment-rich growth that can create 3.3 million new jobs (PM Dept. 2010, 5-6). The investments made by the Malaysian government in education and training is regarded as an effort to ensure that more Malaysians are able to participate in these new opportunities with the end objective of lifting the income of the bottom 40 percent of households from RM 1, 440.00 in 2009 to RM 2, 300.00 in 2015.

The Government Transformation Programme (GTP) can be regarded as a roadmap to achieved the '1 Malaysia Vision' and the 'Economic Transformation Programme (ETP) which aimed at making Malaysia as developed county by 2020. This is a development planning unit led by Prime Minister Najib and his cabinet, and the document of this GTP was spearheaded by the Minister for Unity and Performance Management and the CEO of the PEMANDU in response to the Prime Minister's call for greater accountability of the government and to formulate the 
detail targets. The rationale of this GTP is that the Malaysian government needs a new way of doing things to accelerate and sustain its impact on country economy. Although the GTP only represent as an initial set of actions in areas identified as National Key Result Areas (NKRAs) and Ministerial Key Result Areas (MKRAs) which intended to delivered the mentioned target; nevertheless, as a roadmap it has successfully designed its way in achieving the objective of making Malaysia a high-income country by 2020 through three phases: Phase 1 (2010-2012). An immediate objective of this phase is to establish a new engine for change and deliver substantial outcomes for all Malaysians quickly; Phase 2 (2012-2015). At this stage the Malaysian government expecting the country economy structure already evolved in line with New Economic Model (NEM) where the first sign of a higher income country should be emerging. Phase 3 (2015-2020).In this period of time it is expecting that the fundamental changes to Malaysian society taking place and all Malaysian experiencing a new sense of being Malaysian, with a higher prosperity and better public service.

Looking at the growth rate of the Malaysian economy in the third quarter Gross National Income was better than expected at 5.2 per cent between July and September 2012 amid challenging global economic conditions. Again, the new measurers to speeds the economic growth and creating more jobs opportunities for Malaysians, on November 16, 2012 Prime Minister Mohd Najib unveiled another 20 ETP new projects that will result in RM 26.1 billion to the country's Gross National Income and create 64,284 jobs by 2020 (New Straits Times 2012). According to Prime Minister Mohd Najib, despite continuing global uncertainty, Malaysia remains an attractive destination for investment. As he said that "Our growth remains strong, the fundamentals of our economy are sound and our commitment to structural change encourages investors to see Malaysia as a country that looks to the future" (New Straits Times 2012).

It is believed that with the 20 more ETP mentioned projects certainly would improve further the job market because of an expected increase in the number of jobs generated by the projects, and at the same time also the business supplying goods and services would also benefit from the ETP project, as supplier of good and services for the ETP project would benefit in terms of higher sales as well as revenue growth, and in turn these business will be able to remunerate their employees better and hire more workers; and according to the RAM Holding chief economist, Yeah Kim Leng that the ETP project affirmed Malaysia's attractiveness as an investment destination (New Straits Times 2012).

\section{Global Movement of Moderates Foundation (GMMF)}

As a realist and a pragmatic leader, Mohd Najib is very concerned about what's going on in different parts of the world today, and according to him among the most important challenges confronting the international community today that needs to be addressed collectively, is the challenge of ensuring a just, equitable and durable peace. Mohd Najib has a view that an everlasting peace can be achieved which is based upon the premise of a 'covenant of the willing and not one enforced by way of hegemony through fear and coercion' (Mohd Najib 2010). "One way to achieve such peace is through constructive dialogue which will help in creating a deeper understanding and respect of each other in our conviction to create a better future for all citizens of the world", he added.

He believes that it is impossible for the world community to get rid of world extreme views by force; because violence begets violence, according to him, "the best way to foster tolerance and understanding is not by silencing the voice of hatred but by making the voice of reason louder (Mohd Najib 2012). Furthermore, persuasion, negotiation and co-operation should be the weapons in the face of enmity and malice. He is very concerned on the increasing trend in some parts of the world to perpetuate or even fuel Islamophobia. Attempts to demonize Islam offend the one and a half billion adherents of the religion. It intensifies the divide between the broad Muslim world and the west. The 'real issue' according to Najib is not between Muslims and non-Muslims but between moderates and extremists of all religions, be it Islam, Christianity or Judaism. Across all religions there exist the ugly voices of the periphery to drown 
out the many voices of reason and common sense. Therefore he urges the world community to embark on building a "Global Movement of the Moderate" from all faiths who are committed to work together to combat extremists who have held the world hostage with their bigotry and bias. He repeatedly said that we have to urgently reclaim the centre and the moral high ground that has been usurped from us. He also added "We must choose moderation over extremism and we must choose negotiations over confrontation. We must choose to work together and not against each other" (Mohd Najib 2012).

Moderation according to him is an age-old value, and one that runs right to the heart of the great religions. In Islam, the Prophet Muhammad (PBUH) counsels that "moderation is the best of actions (Khair al-umur ausatuha) ", in Christianity, the Bible says " let your moderation be known unto all men "; and in Judaism, the Torah teaches that moderation in all things is "the way of life" (Mohd Najib 2012) in the truest sense of Jewish custom. According to Mohd Najib, history has been made not by those who espoused extremism but by those who without surrendering their beliefs, stayed true to the path of moderation. He added, we are all familiar with the extraordinary strength of will and leadership of Mahatma Gandhi, Nelson Mandela and Aung San Suu Kyi. Moderates can make a difference whenever they make a stand. Mohd Najib added that it is time for the massed ranks of the moderates everywhere to stand up and to say to the extremists with a single breath a firm, resounding "No".

Malaysia is a country which stands at the geographical cross roads of major civilizations and religions of the world which makes all Malaysian people ready to play their role in promoting religious understanding, harmony and tolerance. To further strengthen the Malaysian process of national unity, as the sixth Prime Minister of Malaysia, Mohd Najib has introduced a philosophy known as 1 Malaysia, which can be regarded as a vision that seeks renewal and rejuvenation to bring all Malaysian people together in a just and harmonious relationship. 1 Malaysia is a call for the acceptance of diversity as a source of greater unity which indicates that Malaysia is a country that is celebrating their multi-ethnic and multireligious society for strategic strength and harmony.

As a democratic country with a multi-racial, multi-religious, multi-cultural society which has benefited from the positive interaction and synergy between the various communities, the country is able to share her experience in managing issues of diversity with other world communities. According to Mohd Najib, Malaysia is a country that has long been synonymous not with extremism but with moderation, tolerance, inclusivity and even acceptance because the Malaysians are aware that they can only become strong when they actively embrace their differences and it is in this spirit that Prime Minister Mohd Najib initiated the first ever meeting of the 'Global Movement of the Moderates' in Putrajaya on January 17, 2012 (Mohd Najib 2012) and the launching of the formation of the Institute of al-Wasatiyyah (Global Movement of the Moderate Foundation (GMMF).

Mohd Najib's concept of moderation is not confined to religious extremism only, instead it is a step which will be able to steer the international community from the dangerous extremes, social, political and economic that could cause the nation lasting damage. He urged international leaders to devise a system that can deliver fairness for "the 99 percent", and not just for those at the top (Mohd Najib 2012). The international community no longer can tolerate the workings of the markets to be value-free or value neutral. According to him markets are the only route to rising global prosperity and sustained, stable growth, but at the same time the international leaders also must do away with unjust, unfair outcomes they can produce when left unchecked, and with the reckless economic practices which makes our global financial system unstable, by quoting the statement of Thomas Jefferson saying that "the selfish spirit of commerce knows no country, and feels no passion of principle but that of gain" (Mohd Najib 2012). Based on this reality the Britain's Chief Rabbi Jonathan Sacks has written of the need for employers, bankers and shareholders to be "guided, even if no-one is watching, by a sense of what is responsible and right." Mohd Najib believes the structures and principles of Islamic finance which has long put public good ahead of an individual gain could contribute something in providing a solid ethical foundation for economic activity. 
Mohd Najib believed that oppression and tyranny can only win out if good men and women stand idly by, unwilling to turn rhetoric into action and opinions into deeds. He urged international leaders come together commit ourselves to change and begin the task of building a new coalition of the moderates for our times. He concluded his call at the $65^{\text {th }}$ Session of the United Nations General Assembly by saying: "It is time for moderates of all countries, of all religions to take back the centre, to reclaim the agenda for peace and pragmatism, and to marginalize the extremists. This is an opportunity for all of us to provide the much needed leadership to bring hope and restore dignity for all" (Mohd Najib 2010). He believed with greater will and collective determination, we will build a more peaceful, secure and equitable world.

As a conclusion, since the early 1990s, intra-Malay politics, specifically the contentious UMNO-PAS rivalry, has dominated Malaysian politics and society, particularly in the north and north-eastern Malay states of Kedah, Perlis, Kelantan and Terengganu. The battle for the hearts and minds of the Malay populace had been largely fought through the propagation of brands of Islam with each contending party claimed most fairly reflected the true teachings of Islam. Throughout the 1990s, the debate on the values and practice of Islam coincided with the aspirations of Tun Mahathir to modernize and industrialize the Malaysian economy. In his aim to transform Malaysia's economy and society, Tun Mahathir's government was criticized by PAS for neglecting the spiritual and religious development of its citizens.

One of Tun Abdullah's immediate tasks on his appointment as Prime Minister was to regain the support of the Malays who had abandoned UMNO for PAS. The results of the historic 1999 general elections, held at the height of Anwar's reformation agenda, was a clear warning to UMNO that it was well on the road to oblivion in the Malay heartland. For Abdullah, whose Islamic credentials gave him some credibility to take on the PAS Islamic scholars on an interpretation of the religion, one way to secure the support of the disenchanted Malay electorate was through the promotion of a more tolerant and compassionate brand of Islamcivilizational Islam(Islam Hadhari). The nebulous nature of this concept suggests, however, that Islam Hadhari was more a political ploy to secure support than a real vision for the practice of this religion in a multi-ethnic and multi-religious society. The government remains embroiled in an attempt to define this concept in an articulate and coherent fashion. It is, however, probably unnecessary, for Abdullah's government to define Islam Hadhari as this study has brought into question the importance of Islam in securing the support of the Malay electorate.

The perceived importance of Islam in understanding the impressive 2004 electoral performance of the NF (BN) was a result of the active promotion of Abdullah as an exemplary Muslim leader. It was, however, the successful propagation of the idea that Abdullah was committed to the flight of poor Malays, his active promotion of his intent to develop the rural economy and his declaration to create a more transparent and credible administration that was most crucial in swinging votes to UMNO in the 2004 general election.

Even before becoming the sixth Prime Minister for Malaysia, Mohd Najib was quite aware that the country cannot afford to coast along and he made it clear that a transformation of the Malaysian economy is a necessity. Najib believed that with the increasing challenge in the global environment that the elements of Malaysia's economy will need to be structurally upgraded in order for the country to avoid the middle income trap and to increase the growth rate. Malaysia needs a model which is more relevant to current times. For that reason he introduced the Economic Transformation Programme (ETP). The ETP is the first time that any effort of this kind has been undertaken in Malaysia's history. This is a comprehensive effort that will transform Malaysia into a high-income nation with a per capita income of about RM 48,000 or USD 15,000 by 2020 . Among the measures which have been designed by the Malaysian government to achieve high-income status is that the country needs to remain sustainable in both economic and environmental term, meeting present needs without compromising those of future generations. 
As a pragmatic leader, Mohd Najib believes that among the most important challenges today is the challenge of ensuring a just, equitable and durable peace. He has a view that an everlasting peace can be achieved which is based upon the premise of a 'covenant of the willing and not one enforce by way of hegemony through fear and coercion'. One way to achieve such peace according to him is through constructive dialogue which will help in creating a deeper understanding and respect of each other in our conviction to create a better future for all citizens of the world.

The real issue is not between Muslims and non-Muslims but between moderates and extremists of all religions, be it Islam, Christianity or Judaism. Therefore, he urge the world community to embark on building a "Global Movement of the Moderate" from all faiths who are committed to work together to combat extremists who have held the world hostage with their bigotry and bias. Mohd Najib said: "We must choose moderation over extremism and we must choose negotiations over confrontation. We must choose to work together and not again each other". Malaysia according to him is a country that has long been synonymous not with extremism but with moderation, tolerance, inclusivity and even acceptance because the Malaysians are aware that they can only become strong when they actively embrace their differences and it is in this spirit Prime Minster Mohd Najib initiated the first ever meeting of the 'Global Movement for Moderates' in Putrajaya on January 17, 2012 and the launching of the formation of the Institute of al-Wasatiyyah (Global Movement of the Moderate Foundation or $G M M F)$.

\section{References}

Ahmad Hussein, Syed. 2002. Muslim politics and the discourse on democracy, In. Democracy in Malaysia: discourse and practices. Richmond: Curzon Press.

Chamil Wariya. 2009. Najib Razak: Prime Minister of Malaysia. Petaling Jaya: MPH Group Publishing Sdn Bhd.

Crouch, H. 1996. Government and society in Malaysia. St Leonard, New South Wales: Allen \& Unwin.

Esposito, J.L. \& Vol. J. O. 1996. Islam and democracy. New York: Oxford University Press.

Farish A Noor. 2004. Islam embedded: the historical development of the Pan-Malaysian Islamic Party PAS (1951-1953). Kuala Lumpur: Malaysian Sociological Research Institute, Vol. 1 $\& 2$.

Funston, J. 1980. Malay politics in Malaysia: a study of PAS and UMNO. Kuala Lumpur: Heinemann.

Gomez, E.T. 2007. Politics in Malaysia. New York: Routledge.

Gullick, J.M. 1995. Malays society in the late nineteenth century. Singapore: Oxford University Press.

Haddad, Y.Y. 1995. Islamist and the challenge of pluralism. Washington D.C.: Georgetown University.

Harrowitz, D. L.1994. The Qur'an and the common law: Islamic law reform and the theory of legal change. Kuala Lumpur: University Malaya Publishers.

Hashim Soffian. 1963. The Relationship between Islam and state in Malaysia. Intisari. Vol. 1, No. 3.

Hong Hai, Lim. 1997. The Malaysian electoral system: its formation and change: Kuala Lumpur: University Malaya Publishers.

Ibrahim, Ahmad. 1997. Pentadbiran Undang-Undang Islam di Malaysia. Kuala Lumpur: Institut Kefahaman Islam Malaysia (IKIM).

Kepel, G. 1998. The Political sociology of Islamism. ISIM Newsletter. Kuala Lumpur: October 25.

Khadijah Md. Khalid. 2007 Islam and Politics in the 2004 General Election. In. Edmund Terence Gomez (ed.), Politics in Malaysia: the Malay dimension. New York: Routledge

Lah Yi, Beh. 2004. PAS want UMNO to explain Islam Hadhari. Malaysiakini. October 6. Kuala Lumpur: http:// www.malaysiakini.com/print.php?Id+30578. 
Najib, Mohd. 2010. Prime Minister Najib Tun Razak's speech at the $65^{\text {th }}$ Session of the United Nations General Assembly. New York: United Nations, Sept 27.

Najib, Mohd. 2011. Speech Dato' Sri Najib Tun Razak Prime Minister of Malaysia. Honolulu: East West Center, November 12.

Najib, Mohd. 2012. Speech Dato' Sri Najib Tun Razak Prime Minister of Malaysia at Global Movement of Moderate Conference. Putrajaya: Kuala Lumpur Convention Centre, January 7.

News Straits Time. March 24, 2004 \& November 17, 2012.

O' Shanessy, M. 2009. The Barisan Nasional: a gramscian perspective of the 2008 Malaysian General Election. Contemporary Southeast Asia. 31(1).

Roff, W. 1967. The Origin of Malay nationalism. Kuala Lumpur: University Malaya Publishers. Yeoh, Oon. 2009. Najib's first 100 days: no honeymoon. Petaling Jaya: Gerakbudaya Enterprise. 